\title{
Allelopathic effects of Sonchus oleraceus L. on the germination and seedling growth of crop and weed species
}

\author{
Nasr Hassan Gomaa ${ }^{1,4}$, Mahmoud Omar Hassan ${ }^{1}$, Gamal Mohammad Fahmy², \\ Luís González ${ }^{3}$, Ola Hammouda ${ }^{1}$ and Atteya Mostafa Atteya ${ }^{1}$
}

Received: 22 November, 2013. Accepted: 18 March, 2014

\begin{abstract}
We assessed the allelopathic effects of the aqueous extract of Sonchus oleraceus dry shoots on the germination and seedling growth of Trifolium alexandrinum, three weed species (Brassica nigra, Chenopodium murale and Melilotus indicus) and S. oleraceus itself. We assayed four different concentrations of the aqueous extract $\left(\mathrm{w} \mathrm{v}^{-1}\right): 1 \%, 2 \%, 3 \%$ and $4 \%$. To determine whether the effects of the extract were attributable to the presence of allelopathic compounds, its osmotic potential or both, we prepared concentrations of polyethylene glycol (PEG) with osmotic potentials equivalent to those of the aqueous extract. All concentrations of the plant extract completely inhibited the germination and seedling growth of $C$. murale. The lowest concentration of the plant extract partially inhibited germination and seedling growth of B. nigra, $M$. indicus and S. oleraceus, whereas the higher concentrations inhibited those parameters completely. The germination of T. alexandrinum was not affected by the aqueous extract at $1 \%$ or $2 \%$. In general, the aqueous extracts were more effective in inhibiting seed germination and seedling growth than were the PEG solutions. Phytochemical analyses revealed that phenols and alkaloids were the most abundant compounds in S. oleraceus dry matter. Our results suggest that the aqueous extract of $S$. oleraceus has an allelopathic effect on some weeds, and its usefulness as a bioherbicide therefore merits further study.
\end{abstract}

Key words: Allelochemicals, aqueous extract, bioherbicide, phytotoxicity

\section{Introduction}

Allelopathy is any beneficial or deleterious effects of a donor plant (including microorganisms) on the growth or development of another biological system, through the release of chemicals into the environment (Rice 1984). These chemical compounds, known as allelochemicals, are secondary metabolites produced naturally by plants.

In agroecosystems, weeds are problematic plants that compete with crops for resources such as mineral nutrients and water. In addition, weeds play a crucial role because they introduce toxins into the soil, thereby directly or indirectly influencing the germination, growth, establishment and yield of various crops (Patterson 1986). Existing weed control practices are expensive and unsafe in relation to the environment and public health. Therefore, it is vital to seek alternative strategies. The biological control of weeds is a topic that has recently garnered much interest. Numerous reports have indicated that plants with inhibitory allelopathic effects show potential as bioherbicides (Xuan et al. 2005; Fernández-Aparicio et al.2008; Gomaa \& AbdElgawad 2012).
The annual species Sonchus oleraceus L. (sow thistle) is a common noxious winter weed in Egypt. It is native to Europe and is widely distributed worldwide, being found in North America, South America, Africa, Asia, Australia and New Zealand (Hyatt 2006). In Egypt, it is found in various locations, such as crop fields, orchards, canal banks, gardens, roadsides, fallow lands and even at sites of uncontrolled water runoff. It dominates many weed communities in winter crops (Gomaa et al. 2012) and can cause serious problems for the cultivated crops. In addition, $S$. oleraceus can be a host for nematodes and aphids, as well as promoting the transmission of plant viruses (Hutchinson et al. 1984). Furthermore, chemical control of this weed could be difficult, because it has developed a degree of resistance to artificial herbicides, such as chlorsulfuron (Adkins et al. 1997).

Several bioactive compounds have been identified in the leaves of Sonchus oleraceus, including alkaloids, flavonoids, tannins, terpenes, steroids and phenols (Yin et al. 2007; Singh 2010). Nevertheless, the scope of S. oleraceus use has been limited to a few areas, such as medicine, where it

\footnotetext{
${ }^{1}$ Department of Botany \& Microbiology, Faculty of Science, Beni-Suef University, Beni-Suef, Egypt

${ }^{2}$ Department of Botany, Faculty of Science, Cairo University, Giza, Egypt

${ }^{3}$ Department of Plant Biology and Soil Science, University of Vigo, Vigo, Spain

${ }^{4}$ Author for correspondence: nhgomaa@yahoo.com
} 
is as an active ingredient in the field of phytotherapy due to its antioxidant activity (McDowell et al. 2011), and pest (insect) control (El-Kamali 2009). With the exception of a study demonstrating that $S$. oleraceus presents toxicity against Artemia salina (Lima et al. 2009), there have been no studies of its allelopathic potential. Therefore, the main goal of this study was to investigate the allelopathic effects of $S$. oleraceus on the seed germination and seedling growth of the crop Trifolium alexandrinum L., three weed species-Brassica nigra (L.) Koch, Chenopodium murale L., and Melilotus indicus (L.) All.) —and itself.

\section{Materials and methods}

\section{Collection and preparation of plant materials}

In 2012, we collected fresh shoots of Sonchus oleraceus, during the fruiting stage (November-December), from various cultivated fields in Beni-Suef governorate, Egypt. The samples were air dried, ground into fine powder and stored in plastic bags in a refrigerator at $2^{\circ} \mathrm{C}$ until use. The seeds of Trifolium alexandrinum (Egyptian clover) were obtained from the Agricultural Research Center in Giza, whereas ripe seeds of the target weeds (Brassica nigra, Chenopodium murale, Melilotus indicus and S. oleraceus) were collected during late April from weed communities intermingling with field crops, such as Egyptian clover, wheat and carrots.

\section{Preparation of the extract}

Forty grams of air-dried shoots of Sonchus oleraceus were extracted by soaking in $1 \mathrm{~L}$ distilled water at $20^{\circ} \mathrm{C}$ for $24 \mathrm{~h}$, with shaking, to yield a concentration of $40 \mathrm{~g}$ dry tissue/ $\mathrm{L}$ $\left(4 \% \mathrm{w} \mathrm{v}^{-1}\right)$. The extract was filtered through two layers of filter paper (no. 1; Whatman Limited, Kent, UK) to remove the plant debris, after which it was centrifuged at 15,000 rpm for $15 \mathrm{~min}$. The supernatant was filtered again through Whatman no. 1 filter paper. Using the stock extract, four different concentrations were prepared by subsequent dilution with sterile distilled water, in final concentrations of $1 \%, 2 \%$, $3 \%$, and $4 \% \mathrm{w} \mathrm{v}^{-1}$, and distilled water was used as a control.

To assess the effect that the osmotic potential of the extract has on seed germination and seedling growth, as well as to exclude the possibility of osmotic interference with the allelopathic effect of the extract, we used polyethylene glycol (PEG) 6000 solution. The osmotic potential of the most concentrated extract $\left(4 \% \mathrm{w} \mathrm{v}^{-1}\right)$ was measured using an osmometer (800 CL; SLAMED, Frankfurt, Germany), with samples of $100 \mu \mathrm{l}$ of the extract defrosted at room temperature $\left(28^{\circ} \mathrm{C}\right)$. The osmotic potential of the $4 \% \mathrm{w}$ $\mathrm{v}^{-1}$ extract of the dry Sonchus oleraceus shoots was -0.25 Osm kg-1 $\mathrm{H}_{2} \mathrm{O}$. A definite weight of PEG $6000(\approx 229 \mathrm{~g})$ was mixed with $1 \mathrm{~L}$ of distilled water and shaken for $12 \mathrm{~h}$ at room temperature (Villela et al. 1991) to obtain a PEG solution of the same osmotic potential as that of $4 \% \mathrm{w} \mathrm{v}^{-1}$ plant extract. We converted $\mathrm{MPa}$ to $\mathrm{Osm} \mathrm{kg} \mathrm{kg}_{2}^{-1} \mathrm{O}$ according to the equation given by Nobel (1983):

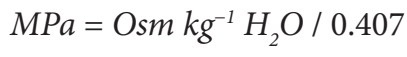

The osmotic potentials of the $1 \%, 2 \%$ and $3 \% \mathrm{w} \mathrm{v}^{-1}$ extract concentrations were determined to be $-0.065,-0.10,-0.17$ Osm kg-1 $\mathrm{H}_{2} \mathrm{O}$, respectively. Through serial dilution of the highest concentration of PEG solution, we prepared additional PEG solutions with corresponding osmotic potentials.

\section{Seed bioassay}

Germination tests were conducted using the different concentrations of plant extract and the corresponding PEG solutions. The seeds of the target species were surface-sterilized with $5.25 \% \mathrm{w} \mathrm{v}^{-1}$ sodium hypochlorite solution for $15 \mathrm{~min}$, rinsed twice with distilled water and placed on filter paper in sterilized $12-\mathrm{cm}$ Petri dishes, each containing 60 seeds and receiving $10 \mathrm{ml}$ of the plant extract or PEG solution. Distilled water was used as a control. All Petri dishes were placed in a dark chamber at $20 \pm 2^{\circ} \mathrm{C}$. Treatments were arranged in a completely randomized design with three replicates. Germination was monitored daily by counting the number of germinated seeds over an eight-day period. The optimal conditions were generally the same for all the target species.

\section{Germination indices and seedling growth}

We calculated the total germination $\left(\mathrm{G}_{\mathrm{T}}\right)$ and the speed of accumulated germination $\left(\mathrm{A}_{\mathrm{S}}\right)$. These indices are highly representative of the germination pattern followed in each treatment, and they are among the most widely cited and used germination indices in the literature (Chiapusio et al. 1997).

The $\mathrm{G}_{\mathrm{T}}$ index (expressed as a percentage) provides an overview of the germination process. It detects possible stimulatory or inhibitory effects on germination, and reports the germination capacity of each species in each situation. The germination percentage was calculated as follows:

$$
G_{T}=(N t \times 100 / N)
$$

where $N t$ is the total number of germinating seeds after the incubation period (8 days), and $N$ is the number of seeds used in the bioassay.

The $A_{S}$ index indicates the effect of a given treatment on the cumulative speed of germination over a given number of time points (Bradbeer 1998; Dias 2001), as calculated with the following equation:

$$
A_{S}=(n 1 / 1+n 2 / 2+n 3 / 3+\ldots+n n / n)
$$

where $n 1, n 2, n 3 \ldots n n$ are the cumulative numbers of germinated seeds at time points $1,2,3 \ldots n$ throughout the 
assay. In such experiments, root and shoot lengths are the most important variables, as indicated by many authors (Souza et al. 2010; Hussain et al. 2011). Root and shoot lengths (expressed as percentages of the control values) were determined eight days after seeding by measuring similar seedlings in each dish.

\section{Phytochemical analyses of Sonchus oleraceus}

\section{Determination of total soluble phenols}

Using Folin-Ciocalteu reagent, we estimated total soluble phenols according to Chun et al. (2003), with minor modification. A 1-g dry shoot sample of Sonchus oleraceus was sonicated in $100 \mathrm{ml}$ of distilled water for $60 \mathrm{~min}$. The solution was allowed to stand for 15 min before filtration with a double layer of filter papers (Whatman no. 1). In a 10$\mathrm{ml}$ volumetric flask, a sample aliquot of $200 \mu \mathrm{l}$ of the aqueous extract was mixed with $400 \mu \mathrm{l}$ of Folin-Ciocalteu reagent. The solution was allowed to stand at room temperature for $8 \mathrm{~min}$ before $200 \mu \mathrm{l}$ of $7.0 \%$ sodium carbonate were added. The solution was completed to $10 \mathrm{ml}$ with distilled water and was allowed to stand for $2 \mathrm{~h}$. The absorbance of the samples was read at $750 \mathrm{~nm}$ in a spectrophotometer (UV-Vis 1601 PC; Shimadzu, Kyoto, Japan). A blank sample with distilled water was used as control. Three replicates were used for each determination. Gallic acid was used as standard to construct a calibration curve. Total soluble phenols are expressed as milligrams of gallic acid equivalents per gram of dry sample ( $\mathrm{mg} \mathrm{g}^{-1}$ dry weight).

\section{Determination of total flavonoids}

The total flavonoid contents were measured by Zou et al. (2004). Three replicated samples of $1 \mathrm{~g}$ dry shoot of Sonchus oleraceus were sonicated in $100 \mathrm{ml} 80 \%$ aqueous methanol for $60 \mathrm{~min}$. In a $10 \mathrm{ml}$ volumetric flask, a $1 \mathrm{ml}$ aliquot of the extracts was diluted with $4 \mathrm{ml}$ distilled water and immediately mixed with $300 \mu \mathrm{l} 5 \%$ sodium nitrite. After $5 \mathrm{~min}, 300 \mu \mathrm{l}$ of $10 \% \mathrm{AlCl}_{3}$ were added. After 6 min, $2 \mathrm{ml}$ of $1 \mathrm{M} \mathrm{NaOH}$ were added to the mixture. The mixture was then immediately diluted by adding $2.4 \mathrm{ml}$ of distilled water and mixing. A blank sample with $80 \%$ aqueous methanol was used as a control. Absorbance was read at $510 \mathrm{~nm}$. Rutin was used as a standard for the calibration curve. Total flavonoid content of the extracts is expressed as milligrams of rutin equivalents per gram of sample ( $\mathrm{mg} \mathrm{g}^{-1}$ dry weight).

\section{Determination of tannins}

The tannin content of the plant tissue was measured according to the method described by van-Burden \& Robinson (1981). Each of three replicates of $1 \mathrm{~g}$ of dry plant sample was sonicated in $100 \mathrm{ml}$ of distilled water for $60 \mathrm{~min}$ and filtered into a $100-\mathrm{ml}$ volumetric flask, after which $10 \mathrm{ml}$ of the filtrate were decanted into a $25-\mathrm{ml}$ measuring flask and mixed with $5 \mathrm{ml}$ of $0.1 \mathrm{M} \mathrm{FeCl}_{3}$ in $0.1 \mathrm{~N} \mathrm{HCl}$ and 0.008 $\mathrm{M}$ potassium ferrocyanide. Absorbance was read at 120 $\mathrm{nm}$. A blank sample was prepared with distilled water and measured at the same wavelength. Tannic acid was used as a standard for the calibration curve. Tannin content in the extracts is expressed as milligrams of tannic acid equivalents per gram of dry sample ( $\mathrm{mg} \mathrm{g}^{-1}$ dry weight).

\section{Determination of alkaloids}

The alkaloid content in the dried shoots of Sonchus oleraceus was determined according to Harborne (2005). Each of three replicates of $5 \mathrm{~g}$ of dry plant sample was placed into a $250-\mathrm{ml}$ beaker, infused with $200 \mathrm{ml}$ of $10 \%$ acetic acid in ethanol, covered and allowed to stand for $4 \mathrm{~h}$. After filtration, the extracts were concentrated to the quarter by heating in a water bath. Concentrated ammonium hydroxide was then added dropwise to the extract for complete precipitation. The whole solution was allowed to settle, after which the precipitate was collected by filtration and weighed. Total alkaloids are expressed as $\mathrm{mg} \mathrm{g}^{-1}$ dry weight.

\section{Determination of saponins}

The total saponins of the plant samples were measured using the method devised by Obadoni \& Ochuko (2001). $5 \mathrm{gm}$ air-dried plant samples were sonicated in $250 \mathrm{ml}$ of $25 \%$ ethanol. The suspension was heated in a water bath at $60^{\circ} \mathrm{C}$ for $4 \mathrm{~h}$, with continuous shaking. After filtration, the residue was again extracted with ethanol (200 $\mathrm{ml}$ of $20 \%$ ethanol). The two extracts were mixed together and reduced to $40 \mathrm{ml}$ over a water bath at $90^{\circ} \mathrm{C}$. In a $250-\mathrm{ml}$ separating funnel, $20 \mathrm{ml}$ of diethyl ether were added to the concentrated extract with vigorous shaking for purification. The ether layer was discarded, and the aqueous layer was recovered. This step was performed thrice. We then added $60 \mathrm{ml}$ of $\mathrm{n}$-butanol. The n-butanol extract was washed twice with 10 $\mathrm{ml}$ of $5 \%$ aqueous sodium chloride. The remaining solution was heated in a water bath. After evaporation, the samples were oven-dried to a constant weight. Three replicates of plant samples were used for this analysis. Saponin content is expressed as $\mathrm{mg} \mathrm{g}^{-1} \mathrm{dry}$ weight.

\section{Identification of phenols and flavonoids by high-} performance liquid chromatography

\section{Extraction of phytochemicals from plant tissues}

In preparation for high-performance liquid chromatography (HPLC), we extracted phytochemicals from plant tissues. Extraction followed the procedure described by Golisz et al. (2007), with certain modifications. We used $1 \mathrm{~g}$ of dry shoot sample and $4 \mathrm{ml}$ of methanol. Rutin and 
quercetin (flavonoids) were extracted with absolute (HPLC grade) methanol at $60^{\circ} \mathrm{C}$ for $30 \mathrm{~min}$ following the procedure described by Andlauer et al. (1999). The remaining flavonoid and phenolic compounds were extracted with $80 \%$ methanol for $12 \mathrm{~h}$ at room temperature. Both extracts were centrifuged at $1400 \mathrm{rpm}$ for $20 \mathrm{~min}$ at $4^{\circ} \mathrm{C}$. The supernatant was filtrated through a $0.45 \mu \mathrm{m}$ syringe filter and stored at $-20^{\circ} \mathrm{C}$ until analysis.

\section{HPLC system}

Free phenolic and flavonoid compounds were detected via absorption at $254 \mathrm{~nm}$ using a UV-Vis detector (LC 1110; GBC Scientific Equipment, Braeside, Australia). Separation was carried out with an HPLC column (Kromasil $5 \mu \mathrm{m}, 250$ $\mathrm{mm} \times 4.6 \mathrm{~mm}$; Phenomenex, Torrance, CA, USA), with WinChrom Chromatography software, version 1.3 (GBC Scientific Equipment). The mobile phase in the HPLC instrument was A: acetonitrile: $0.05 \% \mathrm{H}_{3} \mathrm{PO}_{4}$ (99:1); and B: water: $\mathrm{H}_{3} \mathrm{PO}_{4}(99: 1)$ in gradient elution timetable. We injected $5 \mu$ into the HPLC system where the flow rate was $1 \mathrm{ml} \mathrm{min}{ }^{-1}$. All chemicals and solvents used were HPLC grade. The different phenolic and flavonoid compounds in the plant samples were identified by comparing their retention times with those of known pure authentic phenols (caffeic, ferulic, p-hydroxybenzoic, p-coumaric, syringic, vanillic and sinapic acids, as well as vanillin, catechol and resorcinol) and flavonoids (catechin, rutin and quercetin), all of which were obtained from Sigma-Aldrich (St. Louis, MO, USA). Height and peaks from the pure standards were used for calculations. Concentrations of phenolic and flavonoid compounds are expressed as $\mathrm{mg} \mathrm{ml}^{-1}$.

\section{Statistical analysis}

Data were analyzed using the SPSS Statistics software package, version 19.0 (IBM Corporation, Armonk, NY, USA). Data analysis was first performed using box plots to detect and remove outliers. The Kolmogorov-Smirnov test and Levene's test for homogeneity of variances were then applied to check the data for normality and homoscedasticity, respectively.

The data that presented normality and homoscedasticity were analyzed by the parametric statistic, using one-way ANOVA. When the ANOVA revealed significant differences, we used the results of the Tukey's test for multiple comparisons of means of germination indices and the seedling growth. The data that were not normal or heteroscedastic were analyzed by nonparametric statistics. We applied the nonparametric Kruskal-Wallis test and the Mann-Whitney $U$ test as post hoc tests. We used t-tests to compare concentrations of the plant extract with their corresponding PEG solutions in terms of the germination indices ( $A S$ and $\mathrm{G}_{\mathrm{T}}$ ) and seedling growth. Values of $p<0.05$ were considered statistically significant.

\section{Results}

\section{Germination indices}

The inhibitory effect of the aqueous extract of Sonchus oleraceus shoots was found to depend on the extract concentration and the species studied (Tab. 1). For Chenopodium murale, $\mathrm{G}_{\mathrm{T}}$ and $\mathrm{A}_{\mathrm{S}}$ were both reduced to zero by the plant extract at all concentrations assayed. In specieswere Trifolium alexandrinum, the plant extract had no significant effect on the $G_{T}$ or $A_{S}$ at a concentration of $1 \%$ or $2 \%$, whereas both indices were significantly lowered by application of the plant extract at $3 \%$ and $4 \%$. For the other target species, the $\mathrm{G}_{\mathrm{T}}$ and $\mathrm{A}_{\mathrm{S}}$ were significantly lowered by application of the plant extract at $1 \%$ and were reduced to zero by treatment with the remaining concentrations.

The effect of the osmotic potential of the PEG solutions on the $G_{T}$ and $A_{S}$ was concentration- and species-dependent (Tab. 1). The application of the PEG solution with an osmotic potential of $-0.065 \mathrm{Osm} \mathrm{kg}^{-1} \mathrm{H}_{2} \mathrm{O}$ significantly lowered the $\mathrm{G}_{\mathrm{T}}$ and $\mathrm{A}_{\mathrm{S}}$ of the target weed species $(p<0.05)$. At $-0.1 \mathrm{Osm} \mathrm{kg}^{-1} \mathrm{H}_{2} \mathrm{O}$, the PEG solution significantly lowered the $\mathrm{G}_{\mathrm{T}}$ and $\mathrm{A}_{\mathrm{S}}$ of Brassica nigra, Melilotus indicus and Sonchus oleraceus, whereas it reduced both indices to zero in Chenopodium murale. At osmotic potentials of -0.17 and $-0.25 \mathrm{Osm} \mathrm{kg}^{-1} \mathrm{H}_{2} \mathrm{O}$, the PEG solution significantly lowered the $\mathrm{G}_{\mathrm{T}}$ and $\mathrm{A}_{\mathrm{S}}$ of Trifolium alexandrinum and reduced both indices to zero in the other target species. The difference between the allelopathic effect of the extract and that of its osmotic potential was significant at some of the concentrations applied. For T. alexandrinum, the $\mathrm{G}_{\mathrm{T}}$ was significantly lower when we applied the plant extract at the highest concentration (4\%) than when we applied the PEG solution with the equivalent osmotic potential $(p<$ $0.05)$; and the $A_{S}$ was significantly lower when we applied the plant extract at the $3 \%$ concentration than when we applied the PEG solution with the equivalent osmotic potential $(p<0.05)$. For all three weed species, the $\mathrm{G}_{\mathrm{T}}$ and $\mathrm{A}_{\mathrm{S}}$ were both significantly lower when they were treated with the $1 \%$ plant extract than when they were treated with the corresponding PEG solution. Likewise, the number of germinating seeds of B. nigra, $M$. indicus, and S. oleraceus was significantly lower when we applied the $2 \%$ plant extract than when we applied the corresponding PEG solution $(p<0.05)$.

\section{Seedling growth}

The effects of the Sonchus oleraceus shoot extract on root and shoot lengths of the studied species were, like its effects on the germination indices, concentration- and species-dependent (Tab. 2). The root length of Brassica nigra, Melilotus indicus, and S. oleraceus was significantly reduced by the $S$. oleraceus extract at $1 \%$, which completely inhibited the root growth of Chenopodium murale. The remaining concentrations of the extract completely inhibited the root 
Nasr Hassan Gomaa, Mahmoud Omar Hassan, Gamal Mohammad Fahmy,

Luís González, Ola Hammouda and Atteya Mostafa Atteya

Table 1. Effects of the different concentrations of Sonchus oleraceus extract and of their osmotic potentials (equivalent in polyethylene glycol solution) on total germination and speed of accumulated germination, both expressed as a percentage of control.

\begin{tabular}{|c|c|c|c|c|c|}
\hline \multirow{2}{*}{$\begin{array}{l}\text { Extract concentration }(\Psi \mathrm{s}) \\
\% \mathrm{w} \mathrm{v}^{-1}\left(\mathrm{Osm} \mathrm{kg}^{-1} \mathrm{H}_{2} \mathrm{O}\right)\end{array}$} & T. alexandrinum & B. nigra & C. murale & M. indicus & S. oleraceus \\
\hline & \multicolumn{5}{|c|}{$\begin{array}{l}\text { Total germination } \\
(\%)\end{array}$} \\
\hline $0.0(0.0)^{*}$ & $100^{\mathrm{a}} \pm 0.0\left(100^{\mathrm{a}} \pm 0.0\right)$ & $100^{\mathrm{a}} \pm 7.7\left(100^{\mathrm{a}} \pm 1.4\right)$ & $100^{\mathrm{a}} \pm 6.0\left(100^{\mathrm{a}} \pm 4.3\right)$ & $100^{\mathrm{a}} \pm 0.0\left(100^{\mathrm{a}} \pm 0.0\right)$ & $100^{\mathrm{a}} \pm 5.7\left(100^{\mathrm{a}} \pm 8.5\right)$ \\
\hline $1.0(-0.065)$ & $100^{\mathrm{a}} \pm 0.0\left(100^{\mathrm{a}} \pm 0.0\right)$ & $22.56^{\mathrm{b}} \pm 7.3\left(75.5^{\mathrm{b}} \pm 2.3\right)^{* *}$ & $0.0^{\mathrm{b}} \pm 0.0\left(30.9^{\mathrm{b}} \pm 2.5\right)^{\star *}$ & $1.3^{\mathrm{b}} \pm 1.7\left(93.1^{\mathrm{b}} \pm 2.4\right)^{* *}$ & $45^{\mathrm{b}} \pm 3.8\left(60^{\mathrm{b}} \pm 10.6\right)^{* *}$ \\
\hline $2.0(-0.10)$ & $100^{\mathrm{a}} \pm 0.0\left(100^{\mathrm{a}} \pm 0.0\right)$ & $0.0^{c} \pm 0.0\left(27.3^{c} \pm 1.4\right)^{* *}$ & $0.0^{\mathrm{b}} \pm 0.0\left(0.0^{\mathrm{c}} \pm 0.0\right)$ & $0.0^{\mathrm{b}} \pm 0.0\left(40.6^{\mathrm{c}} \pm 1.3\right)^{\star *}$ & $0.0^{c} \pm 0.0\left(22.2^{c} \pm 3.6\right)^{* *}$ \\
\hline $3.0(-0.17)$ & $83.3^{\mathrm{b}} \pm 1.4\left(84^{\mathrm{b}} \pm 1.6\right)$ & $0.0^{\mathrm{c}} \pm 0.0\left(0.0^{\mathrm{d}} \pm 0.0\right)$ & $0.0^{b} \pm 0.0\left(0.0^{c} \pm 0.0\right)$ & $0.0^{\mathrm{b}} \pm 0.0\left(0.0^{\mathrm{d}} \pm 0.0\right)$ & $0.0^{\mathrm{c}} \pm 0.0\left(0.0^{\mathrm{d}} \pm 0.0\right)$ \\
\hline $4.0(-0.25)$ & $11.3^{c} \pm 1.2\left(17.75^{c} \pm 2.1\right)^{\star *}$ & $0.0^{\mathrm{c}} \pm 0.0\left(0.0^{\mathrm{d}} \pm 0.0\right)$ & $0.0^{\mathrm{b}} \pm 0.0\left(0.0^{\mathrm{c}} \pm 0.0\right)$ & $0.0^{\mathrm{b}} \pm 0.0\left(0.0^{\mathrm{d}} \pm 0.0\right)$ & $0.0^{\mathrm{c}} \pm 0.0\left(0.0^{\mathrm{d}} \pm 0.0\right)$ \\
\hline \multirow{2}{*}{$\begin{array}{l}\text { Extract concentration }(\Psi \mathrm{s}) \\
\% \mathrm{w} \mathrm{v}^{-1}\left(\mathrm{Osm} \mathrm{kg} \mathrm{kg}^{-1} \mathrm{H}_{2} \mathrm{O}\right)\end{array}$} & T. alexandrinum & B. nigra & C. murale & M. indicus & S. oleraceus \\
\hline & \multicolumn{5}{|c|}{$\begin{array}{c}\text { Speed of accumulated germination } \\
(\%)\end{array}$} \\
\hline $0.0(0.0)^{*}$ & $100^{\mathrm{a}} \pm 1.0\left(100^{\mathrm{a}} \pm 0\right)$ & $100^{\mathrm{a}} \pm 3.0\left(100^{\mathrm{a}} \pm 0.02\right)$ & $100^{\mathrm{a}} \pm 0.08\left(100^{\mathrm{a}} \pm 0.04\right)$ & $100^{\mathrm{a}} \pm 0.02\left(100^{\mathrm{a}} \pm 1.0\right)$ & $100^{\mathrm{a}} \pm 0.03\left(100^{\mathrm{a}} \pm 0.08\right)$ \\
\hline $1.0(-0.065)$ & $99.0^{\mathrm{a}} \pm 1.0\left(100^{\mathrm{a}} \pm 0\right)$ & $8.7^{\mathrm{b}} \pm 3.0\left(69^{\mathrm{b}} \pm 0.03\right)^{* *}$ & $0.0^{\mathrm{b}} \pm 0\left(28.25^{\mathrm{b}} \pm 0.02\right)^{* *}$ & $2.0^{\mathrm{b}} \pm 0\left(91.3^{\mathrm{b}} \pm 0.9\right)^{* *}$ & $37.0 \mathrm{~b} \pm 0.03(58.6 \mathrm{~b} \pm 0.09)^{* *}$ \\
\hline $2.0(-0.10)$ & $96^{a} \pm 2.0\left(99.5^{a} \pm 0.01\right)$ & $0.0^{c} \pm 0\left(11^{c} \pm 0.01\right)^{* *}$ & $0.0^{\mathrm{b}} \pm 0.0\left(0.0^{\mathrm{c}} \pm 0.0\right)$ & $0.0^{b} \pm 0.0\left(32^{c} \pm 0.3\right)^{* *}$ & $0.0^{c} \pm 0.0\left(18^{c} \pm 0.03\right)^{* *}$ \\
\hline $3.0(-0.17)$ & $47.4^{\mathrm{b}} \pm 4.0\left(71.8^{\mathrm{b}} \pm 0.01\right)^{* *}$ & $0.0^{\mathrm{c}} \pm 0.0\left(0.0^{\mathrm{d}} \pm 0.0\right)$ & $0.0^{\mathrm{b}} \pm 0.0\left(0.0^{\mathrm{c}} \pm 0.0\right)$ & $0.0^{\mathrm{b}} \pm 0.0\left(0.0^{\mathrm{d}} \pm 0.0\right)$ & $0.0^{\mathrm{c}} \pm 0.0\left(0.0^{\mathrm{d}} \pm 0.0\right)$ \\
\hline $4.0(-0.25)$ & $2.0^{\mathrm{c}} \pm 0.0\left(2.8^{\mathrm{c}} \pm 0.5\right)$ & $0.0^{\mathrm{c}} \pm 0.0\left(0.0^{\mathrm{d}} \pm 0.0\right)$ & $0.0^{\mathrm{b}} \pm 0.0\left(0.0^{\mathrm{c}} \pm 0.0\right)$ & $0.0^{\mathrm{b}} \pm 0.0\left(0.0^{\mathrm{d}} \pm 0.0\right)$ & $0.0^{\mathrm{c}} \pm 0.0\left(0.0^{\mathrm{d}} \pm 0.0\right)$ \\
\hline
\end{tabular}

$\Psi \mathrm{s}$ - solute potential (osmotic potential).

Values of parameters in parentheses correspond to the effect of the osmotic potential.

Means followed by the same lower-case letter in the same column do not differ significantly at the 0.05 probability level, according to Tukey's test.

* Control.

** Significant difference $(p<0.05)$ between the effect of the plant extract and that of the corresponding polyethylene glycol solution, according to t-tests.

Table 2. Effects of the different concentrations of Sonchus oleraceus extract and of their osmotic potentials (equivalent in polyethylene glycol solution) on the root and shoot lengths of eight-day-old seedlings of the studied species, both expressed as a percentage of control.

\begin{tabular}{|c|c|c|c|c|c|}
\hline \multirow{2}{*}{$\begin{array}{l}\text { Extract concentration }(\Psi \mathrm{s}) \\
\% \mathrm{w} \mathrm{v}^{-1}\left(\mathrm{Osm} \mathrm{kg}^{-1} \mathrm{H}_{2} \mathrm{O}\right)\end{array}$} & T. alexandrinum & B. nigra & C. murale & M. indicus & S. oleraceus \\
\hline & \multicolumn{5}{|c|}{$\underset{(\%)}{\text { Root } \operatorname{le~} \mathrm{gth}}$} \\
\hline $0.0(0.0)^{*}$ & $100^{b} \pm 10\left(100^{a} \pm 6.2\right)$ & $100^{\mathrm{a}} \pm 12.6\left(100^{\mathrm{a}} \pm 3.2\right)$ & $100^{\mathrm{a}} \pm 12.3\left(100^{\mathrm{a}} \pm 12.6\right)$ & $100^{\mathrm{a}} \pm 16.6\left(100^{\mathrm{a}} \pm 15.4\right)$ & $100^{\mathrm{a}} \pm 5.7\left(100^{\mathrm{a}} \pm 18.6\right)$ \\
\hline $1.0(-0.065)$ & $123^{\mathrm{a}} \pm 16.9\left(96^{\mathrm{a}} \pm 5.9\right)^{* *}$ & $57.9^{\mathrm{b}} \pm 7.1\left(99.8^{\mathrm{a}} \pm 3.8\right)^{* *}$ & $0.0^{\mathrm{b}} \pm 0.0\left(100^{\mathrm{a}} \pm 15.9\right)^{* *}$ & $51^{\mathrm{b}} \pm 5.2\left(54.8^{\mathrm{b}} \pm 5.7\right)$ & $82.2^{\mathrm{b}} \pm 3.8\left(83^{\mathrm{b}} \pm 10.8\right)$ \\
\hline $2.0(-0.10)$ & $74.1^{\mathrm{c}} \pm 14.6\left(75.2^{\mathrm{b}} \pm 7.2\right)$ & $0.0^{\mathrm{c}} \pm 0.0\left(90.6^{\mathrm{b}} \pm 6.8\right)^{* *}$ & $0.0^{\mathrm{b}} \pm 0.0\left(0.0^{\mathrm{b}} \pm 0.0\right)$ & $0.0^{c} \pm 0\left(29.5^{c} \pm 3.9\right)^{* \star}$ & $0.0^{c} \pm 0.0\left(33.5^{c} \pm 6.6\right)^{* *}$ \\
\hline $3.0(-0.17)$ & $47.7^{\mathrm{d}} \pm 8.7\left(55.3^{\mathrm{c}} \pm 6.7\right)^{* *}$ & $0.0^{c} \pm 0.0\left(0.0^{c} \pm 0.0\right)$ & $0.0^{\mathrm{b}} \pm 0.0\left(0.0^{\mathrm{b}} \pm 0.0\right)$ & $0.0^{\mathrm{c}} \pm 0.0\left(0.0^{\mathrm{d}} \pm 0.0\right)$ & $0.0^{\mathrm{c}} \pm 0.0\left(0.0^{\mathrm{d}} \pm 0.0\right)$ \\
\hline $4.0(-0.25)$ & $29.7^{\mathrm{d}} \pm 10.3\left(34.2^{\mathrm{d}} \pm 7.7\right)^{\star \star}$ & $0.0^{c} \pm 0.0\left(0.0^{c} \pm 0.0\right)$ & $0.0^{\mathrm{b}} \pm 0.0\left(0.0^{\mathrm{b}} \pm 0.0\right)$ & $0.0^{\mathrm{c}} \pm 0.0\left(0.0^{\mathrm{d}} \pm 0.0\right)$ & $0.0^{\mathrm{c}} \pm 0.0\left(0.0^{\mathrm{d}} \pm 0.0\right)$ \\
\hline \multirow{2}{*}{$\begin{array}{l}\text { Extract concentration ( } \Psi \text { s) } \\
\% \mathrm{w} \mathrm{v}^{-1}\left(\mathrm{Osm} \mathrm{kg}{ }^{-1} \mathrm{H}_{2} \mathrm{O}\right)\end{array}$} & T. alexandrinum & B. nigra & C. murale & M. indicus & S. oleraceus \\
\hline & \multicolumn{5}{|c|}{$\begin{array}{c}\text { Shoot le ngth } \\
(\%)\end{array}$} \\
\hline $0.0(0.0)^{*}$ & $100^{a} \pm 7.6\left(100^{a} \pm 9.7\right)$ & $100^{a} \pm 11.5\left(100^{a} \pm 8.7\right)$ & $100^{\mathrm{a}} \pm 14.3\left(100^{\mathrm{a}} \pm 8.0\right)$ & $100^{\mathrm{a}} \pm 11.5\left(100^{\mathrm{a}} \pm 15\right)$ & $100^{\mathrm{a}} \pm 17\left(100^{\mathrm{a}} \pm 14.9\right)$ \\
\hline $1.0(-0.065)$ & $84.7^{b} \pm 9.6\left(89.7^{b} \pm 3.2\right)^{* *}$ & $65.7^{\mathrm{b}} \pm 8.8\left(82.1^{\mathrm{b}} \pm 4\right)^{* *}$ & $0.0^{b} \pm 0.0\left(98.6^{\mathrm{a}} \pm 9.4\right)^{* *}$ & $69.0^{\mathrm{b}} \pm 9\left(86.1^{\mathrm{b}} \pm 8.1\right)^{* *}$ & $75.7^{b} \pm 22.9\left(86^{b} \pm 10.7\right)^{* *}$ \\
\hline $2.0(-0.10)$ & $71.8^{\mathrm{b}} \pm 9.3\left(67.94^{\mathrm{c}} \pm 8.8\right)$ & $0.0^{c} \pm 0.0\left(40.2^{c} \pm 3.9\right)^{* *}$ & $0.0^{\mathrm{b}} \pm 0.0\left(0.0^{\mathrm{b}} \pm 0.0\right)$ & $0.0^{c} \pm 0.0\left(35.5^{c} \pm 5.3\right)^{* *}$ & $0.0^{c} \pm 0.0\left(37.6^{c} \pm 6.4\right)^{* *}$ \\
\hline $3.0(-0.17)$ & $50.4^{\mathrm{c}} \pm 10.5\left(53^{\mathrm{d}} \pm 5.9\right)$ & $0.0^{\mathrm{c}} \pm 0.0\left(0.0^{\mathrm{d}} \pm 0.0\right)$ & $0.0^{\mathrm{b}} \pm 0.0\left(0.0^{\mathrm{b}} \pm 0.0\right)$ & $0.0^{\mathrm{c}} \pm 0.0\left(0^{\mathrm{d}} \pm 0.0\right)$ & $0.0^{\mathrm{c}} \pm 0.0\left(0.0^{\mathrm{d}} \pm 0.0\right)$ \\
\hline $4.0(-0.25)$ & $23.8^{\mathrm{c}} \pm 5.2\left(26.72^{\mathrm{e}} \pm 3.6\right)$ & $0.0^{\mathrm{c}} \pm 0.0\left(0.0^{\mathrm{d}} \pm 0.0\right)$ & $0.0^{\mathrm{b}} \pm 0.0\left(0.0^{\mathrm{b}} \pm 0.0\right)$ & $0.0^{\mathrm{c}} \pm 0\left(0.0^{\mathrm{d}} \pm 0.0\right)$ & $0.0^{\mathrm{c}} \pm 0.0\left(0.0^{\mathrm{d}} \pm 0.0\right)$ \\
\hline
\end{tabular}

Is - solute potential (osmotic potential).

Values of parameters in parentheses correspond to the effect of the osmotic potential.

Means followed by the same lower-case letter in the same column do not differ significantly at the 0.05 probability level, according to Tukey's test.

* Control.

** Significant difference $(p<0.05)$ between the effect of the plant extract and that of the corresponding polyethylene glycol solution, according to t-tests. 
growth of all weed species. In Trifolium alexandrinum, application of the $1 \%$ extract significantly $(p<0.05)$ increased root length by $23 \%$, whereas the higher concentrations induced significant gradual reductions in root length. The effect of S. oleraceus extract on shoot length of the weed species exhibited the same pattern as that observed for root growth. At all concentrations, the plant extract inhibited the shoot elongation of T. alexandrinum, and the degree of that inhibition increased gradually in parallel with increasing concentrations of the extract.

The effects of the PEG solutions varied among species (Tab. 2). At an osmotic potential of -0.065 (equivalent to that of the plant extract at a concentration of $1 \%$ ), the PEG solution significantly inhibited the root growth of Melilotus indicus and Sonchus oleraceus $(p<0.05)$, as well as the shoot growth of all target species except Chenopodium murale. In general, the inhibition of root and shoot growth increased in parallel with decreasing osmotic potentials (values that were more negative). The roots of Brassica nigra and $C$. murale were significantly shorter when those weeds were treated with $1 \%$ plant extract than when they were treated with the corresponding PEG solution. For all weed species, shoots were significantly shorter when the $1 \%$ plant extract was applied than when the corresponding PEG solution was applied $(p<0.05)$. When treated with PEG solution at an osmotic potential of $-0.1 \mathrm{Osm} \mathrm{kg}^{-1} \mathrm{H}_{2} \mathrm{O}$ (equivalent to that of the plant extract at a concentration of $2 \%), B$. nigra and $M$. indicus exhibited root and shoot lengths significantly greater than those exhibited by the same species treated with the corresponding concentration of $S$. oleraceus extract. For Trifolium alexandrinum, root length was significantly greater in seedlings treated with $1 \%$ plant extract than in those treated with the corresponding PEG solution. The inverse was true at higher concentrations of $S$. oleraceus extract (3\% and $4 \%$ ), the application of which resulted in $T$. alexandrinum roots being significantly shorter than those produced under the effects of the corresponding PEG solutions. The shoot lengths of T. alexandrinum seedlings were significantly greater when we applied the PEG solution at the osmotic potential of $-0.065 \mathrm{Osm} \mathrm{kg}^{-1} \mathrm{H}_{2} \mathrm{O}$ than when we applied the $S$. oleraceus extract at the corresponding concentration (1\%).

\section{Phytochemical analyses and HPLC of Sonchus oleraceus}

The quantitative determination of some phytochemical constituents of Sonchus oleraceus shoots is summarized in Tab. 3. Among the compounds detected, tannins were predominant (118.21 $\mathrm{mg} \mathrm{g}^{-1}$ dry weight). Saponins, total phenols and alkaloids were also detected in relatively high amounts (73.0, 66.5 and $52.3 \mathrm{mg} \mathrm{g}^{-1}$ dry weight, respectively). In contrast, the flavonoid content was low $\left(2.95 \mathrm{mg} \mathrm{g}^{-1}\right.$ dry weight).

The HPLC analysis of the dry shoots of Sonchus oleraceus confirmed the presence of eight phenolic compounds
Table 3. Phytochemical composition of Sonchus oleraceus dry shoots. ${ }^{\star}$

\begin{tabular}{lc}
\hline \multirow{2}{*}{ Category } & Concentration \\
\cline { 2 - 2 } Total Phenols & $\left(\mathrm{mg} \mathrm{g}^{-1}\right.$ dry weight $)$ \\
Flavonoids & $66.5 \pm 8.92$ \\
Tannins & $2.95 \pm 0.44$ \\
Alkaloids & $118.21 \pm 4.37$ \\
Saponins & $52.3 \pm 12.01$ \\
\hline
\end{tabular}

${ }^{*}$ Values are mean \pm SD.

and three flavonoids (Tab. 4). Among the phenolic compounds, catechol and ferulic acid were the most abundant (10.4 and $7.92 \mathrm{mg} \mathrm{ml}^{-1}$, respectively), whereas caffeic and p-coumaric acids were the least abundant (0.014 and 0.02 $\mathrm{mg} \mathrm{ml} \mathrm{m}^{-1}$, respectively). In addition, catechin and rutin were the dominant flavonoid compounds (1.52 and 1.40 $\mathrm{mg} \mathrm{ml}^{-1}$, respectively), collectively representing a content approximately 15.2 -fold greater than that of quercetin (0.092 $\left.\mathrm{mg} \mathrm{ml}^{-1}\right)$.

\section{Discussion}

The present study revealed that the aqueous extract of Sonchus oleraceus had inhibitory effects on the germination indices $\left(G_{T}\right.$ and $\left.A_{S}\right)$ and seedling growth of the test species, as well as on those of itself. In addition, our bioassay indicated that the allelopathic effects of $S$. oleraceus extract on the test species are concentration- and species-dependent. The rate of seed germination decreased in parallel with increasing concentrations of the extract. Previous studies have demonstrated that allelopathic plants can affect the germination indices $\left(G_{T}\right.$ and $\left.A_{S}\right)$ and seedling growth of many target species (Hussain et al. 2011; Novoa et al. 2012). Increasing the inhibitory effect by altering the extract concentration is in accordance with previous studies (Hussain et al. 2011; Gomaa \& AbdElgawad 2012). In the present study, growth inhibition was recorded in the seedlings of all weed species, as well as in the shoots of Trifolium alexandrinum, at all concentrations assayed. Reduction in the seedling growth of the target species in this study may be attributed to reduced cell division of the seedlings, because the phenolic allelochemicals could inhibit cell division and alter the ultrastructure of the cells (Li et al. 2010).

The spectrophotometric analyses of Sonchus oleraceus indicated the presence of several classes of compounds: phenols, flavonoids, tannins, saponins and alkaloids. These compounds are known to affect the growth of many plants (Hiag 2008). Various phytochemicals, including phenols, sesquiterpenes, flavonoids, terpenes and alkaloids, exhibit strong phytotoxicity (Qasem \& Foy 2001). Arowosegbe et al. (2012) attributed the inhibitory effect of the aqueous extract of Aloe ferox to such chemical constituents. The inhibitory 
Table 4. Quantitative high-performance liquid chromatography analysis of the concentrations and retention time of phenolic and flavonoid compounds in the aqueous extracts of Sonchus oleraceus shoots.

\begin{tabular}{lcc}
\hline \multirow{2}{*}{ Compounds } & Concentration & Retention time \\
\cline { 2 - 3 } & $\left(\mathrm{mg} \mathrm{m}^{-1}\right)$ & $(\mathrm{min})$ \\
\hline Phenols & & \\
Catechol & 10.4 & 2.68 \\
Caffeic acid & 0.014 & 2.5 \\
Ferulic acid & 7.92 & 4.28 \\
p-hydroxybenzoic acid & 0.61 & 3.43 \\
p-coumaric acid & 0.02 & 4.92 \\
Resorcinol & 0.745 & 2.85 \\
Sinapic acid & 2.5 & 3.17 \\
Vanillic acid & 0.133 & 4.55 \\
Flavonoids & & \\
Catechin & 1.52 & 7.52 \\
Rutin & 1.40 & 7.91 \\
Quercetin & 0.092 & 8.26 \\
\hline
\end{tabular}

action of S. oleraceus might therefore be attributed to the presence of the phytochemicals detected in the plant tissues. Various authors have attributed the inhibition of seed germination and seedling growth to the release of phenolic compounds (Fahmy et al. 2012; Xu et al. 2013). Phenols as well as the other detected compounds were previously reported in the tissues of S. oleraceus by El-Kamali (2009). Quantification of phytochemicals in the current study showed that the total phenolic content $\left(66.5 \mathrm{mg} \mathrm{g}^{-1}\right.$ dry weight) was higher than that reported by Yin et al. (2007) in the same species ( $40.5 \mathrm{mg} \mathrm{g}^{-1}$ dry weight). However, the total flavonoid content reported in our study $(\approx 3 \mathrm{mg}$ $\mathrm{g}^{-1}$ dry weight) was much lower than that reported by the abovementioned authors (118.1 $\mathrm{mg} \mathrm{g}^{-1}$ dry weight). Another study, conducted by Jimoh et al. (2011), confirmed the presence of phenols and flavonoids in S. oleraceus tissues (6.07 and $1.21 \mathrm{mg} \mathrm{g}^{-1} \mathrm{dry}$ weight, respectively). This divergence in the amounts of the detected compounds in S. oleraceus might be attributed to the different habitat conditions in which the species grow. Compared with those of other species, the total phenolic and flavonoid contents recorded for S. oleraceus in our study are higher than those reported by Hue et al. (2012) in the sweet potato (Ipomoea batatas), in which the total phenolic content was $27.8-53.5 \mathrm{mg} \mathrm{g}^{-1}$ dry weight, and the flavonoid content was $0.096-0.263 \mathrm{mg}$ $\mathrm{g}^{-1}$ dry weight. In addition, the total phenolic content in $S$. oleraceus is comparable to the $59.43 \mathrm{mg} \mathrm{g}^{-1}$ dry weight recorded by Song et al. (2010) in the air potato (Dioscorea bulbifera). This suggests that $S$. oleraceus contains relatively high amounts of phenols compared with some other species. In general, the presence of high levels of secondary metabolites in a given species can enhance its allelopathic potential because many of these compounds interfere with various mechanisms of action and could influence a number of target sites (Lotina-Hennsen et al. 2006).

Through HPLC analysis, we confirmed the presence of phenols (catechol and resorcinol, as well as some phenolic acids, such as ferulic, sinapic, vanillic, p-hydroxybenzoic, caffeic and p-coumaric acids) and flavonoids (catechin, rutin and quercetin). To our knowledge, this was the first attempt to detect such compounds in Sonchus oleraceus. Numerous phenolic compounds similar to those identified in this study have been reported by others who investigated the allelopathic potentials of several plant species (Djurdjević et al.2011; Fahmy et al. 2012). For example, the concentration of catechol reported in the present study $\left(10.40 \mathrm{mg} \mathrm{ml}^{-1}\right)$ was considerably higher than that recorded by Fahmy et al. (2012) in Pluchea dioscoridis (0.60 $\left.\mathrm{mg} \mathrm{ml}^{-1}\right)$, while vanillic acid and rutin were approximately the same in both species. The compounds analyzed by HPLC in S. oleraceus may be reasonable candidates for the inhibition which occurred in germination and seedling growth of the target species. This notion was supported by Fahmy et al. (2012) who showed that catechol, syringic acid and rutin significantly reduced the seedling growth of Corchorus olitorius. The authors also showed that catechol exhibited a stronger inhibitory effect than did syringic acid and rutin. Therefore, catechol, which presented the highest concentration of the phenolic and flavonoid compounds detected here in S. oleraceus, might be an effective allelochemical against the target species in our study. However, certain flavonoids, including rutin and quercetin, have been found to exert an inhibitory effect on the germination and seedling growth of radish (Basile et al. 2000). In addition, Golisz et al. (2007) concluded that rutin is the major contributor to the allelopathic activity of buckwheat. Therefore, the flavonoids detected in S. oleraceus, rutin in particular, might play a significant role in the resulting inhibition. Reductions in seedling growth might be attributable to the involvement of the phenols, which can suppress the synthesis of protein and nucleic acids and inactivate several enzymes in the growing plants (Chou 2006).

Our data indicate that, among the species studied, the weeds were more sensitive to the Sonchus oleraceus extract than was the crop (Trifolium alexandrinum). In contrast with what was observed for the weed species, the germination of Trifolium alexandrinum was not affected by the application of the plant extract at either $1 \%$ or $2 \%$. This observation is consistent with that of Al-Sherif et al. (2013), who showed that Egyptian clover and wheat are less sensitive to the extracts of Brassica nigra than are the weed species, Phalaris paradoxa and Sisymbrium irio. Previous studies have indicated that weed species might vary in their response/ tolerance to phytotoxicity (Batish et al. 2004; Gomaa \& AbdElgawad 2012).

Our results confirm the autotoxic nature of Sonchus oleraceus. Autotoxicity is an intraspecific type of allelopathy, occurring when a plant species releases chemical substances that inhibit or delay the germination and growth of the 
same plant species (Alias et al. 2003; Hegab \& Ghareib 2009; Gomaa \& AbdElgawad 2012). The autotoxicity of $S$. oleraceus might have implications for the biocontrol of $S$. oleraceus itself.

In general, the application of PEG solutions with osmotic potentials equivalent to those of the applied extract concentrations inhibited the germination and seedling growth of the target species, although it was to a lesser degree than did the corresponding concentrations of the extract. This suggests that the allelopathic and osmotic potentials of Sonchus oleraceus extract both contribute to the inhibition of germination and seedling growth of the target species. Previous studies confirmed the significant role of both allelopathic and osmotic effects of plant extracts in inhibiting seed germination and seedling growth (Wardle et al. 1992; Souza et al. 2010).

In conclusion, our results show that allelopathic and osmotic effects of the aqueous extract of the Sonchus oleraceus shoots both suppressed germination and seedling growth of the target species. That inhibition was concentration- and species- dependent. The phytochemical analyses revealed the presence of several compounds that might increase the allelopathic potential of $S$. oleraceus. These natural products could be used as "eco-friendly" bioherbicides for weed control. Evaluation of the allelopathic potential of $S$. oleraceus under field conditions is an important future guideline.

\section{Acknowledgments}

The authors thank the staff members of the Department of Botany \& Microbiology at the Beni-Suef University Faculty of Science, in the city of Beni-Suef, Egypt, for the technical assistance provided during the development of this study.

\section{References}

Adkins; S.W.; Wills, D.; Boersma, M.; Walker, S.R.; Robinson, G.; McLeod, R.J. \& Einam, J.P. 1997. Weeds resistant to chlorsulfuron and atrazine from the north-east grain region of Australia. Weed Research 37: 343-349.

Alias, J.C.; Sosa, T.; Escudero, J.C. \& Chaves, N. 2003. Autotoxicity against germination and seedling emergence in Cistus ladanifer L. Journal of Arid Environments 55: 275-285.

Al-Sherif, E.; Hegazy, A.K.; Gomaa, N.H. \& Hassan, M.O. 2013. Allelopathic effect of black mustard tissues and root exudates on some crops and weeds. Planta Daninha 31: 11-19.

Andlauer, W.; Martena, M.J. \& Fürst, P. 1999. Determination of selected phytochemicals by reversed-phase high-performance liquid chromatography combined with ultraviolet and mass spectrometric detection. Journal of Chromatography A 849: 341-348.

Arowosegbe, S.; Wintola, O.A. \& Afolayan, A.J. 2012. Phytochemical constituents and allelopathic effect of Aloe ferox Mill. root extract on tomato. Journal of Medicinal Plants Research 6: 2094-2099.

Basile, A.; Sorbo, S.; Giordano, S.; Ricciardi, L.; Ferrara, S.; Montesano, D.; Castaldo Cobianchi, R.; Vuotto, M.L. \& Ferrara, L. 2000. Antibacterial and allelopathic activity of extract from Castanea sativa leaves. Fitoterapia; 71: 110-116
Batish, D.R.; Setia, N.; Singh, H.B. \& Kohli, R.K. 2004. Phytotoxicity of lemon-scented eucalypt oil and its potential use as a bioherbicide. Crop Protection 23: 1209-1214.

Bradbeer, J.W. 1998. Seed dormancy and germination. Glasgow, Backie \& Son. Chiapusio, G.; Sanchez, A.M.; Reigosa, M.J.; González, L. \& Pellissier, F. 1997. Do germination indices adequately reflect allelochemical effects on the germination process? Journal of Chemical Ecology 23: $2445-2453$

Chou, C. H. 2006. Introduction to allelopathy. Pp. 1 - 9. In: Reigosa, M.J.; Pedrol, N. \& Gonzalez, L. (Eds.). Allelopathy: A Physiological Process with Ecological Implications. The Netherlands, Springer.

Chun, O.K.; Kim, D.O. \& Lee, C.Y. 2003. Superoxide radical scavenging activity of the major polyphenols in fresh plums. Journal of Agriculture and Food Chemistry 51: 8067-8072.

Dias, L.S. 2001. Describing phytotoxic effects on cumulative germination. Journal of Chemical Ecology 27: 411-418.

Djurdjević, L.; Mitrović, M.; Gajić, G.; Jarić, S.; Kostić, O.; Oberan, L. \& Pavlović, P. 2011. An allelopathic investigation of the domination of the introduced invasive Conyza canadensis L. Flora 206: 921-927.

EL-Kamali, H.H. 2009. Effect of certain medicinal plants extracts against storage pest, Tribolium Castaneum Herbst. American-Eurasian Journal of Sustainable Agriculture 3: 139-142.

Fahmy, G.M.; Al-Sawaf, N.A.; Turki, H. \& Ali, H.I. 2012. Allelopathic potential of Pluchea dioscoridis (L.) DC. Journal of Applied Science Research 8: 3129-3142.

Fernández-Aparicio, M.; Emeran, A.A. \& Rubiales, D. 2008. Control of Orobanche crenata in legumes intercropped with fenugreek (Trigonella foenum-graecum). Crop Protection 27: 653-659.

Golisz, A.; Lata, B.; Gawronski, S.W. \& Fujii, Y. 2007. Specific and total activities of allelochemicals identified in buckwheat. Weed Biology and Management 7:164-171.

Gomaa, N.H. \& AbdElgawad, H.R. 2012. Phytotoxic effects of Echinochloa colona (L.) Link. (Poaceae) extracts on the germination and seedling growth of weeds. Spanish Journal of Agricultural Research 10: 492-501.

Gomaa, N.H.; Al Sherif, E.A.; Hegazy, A.K. \& Hassan, M.O. 2012. Floristic diversity and vegetation analysis of Brassica nigra (L.) Koch communities. Egyptian Journal of Biology 14: 63-72.

Harborne, J.B. 2005. Phytochemical methods - A guide to modern techniques of plant analysis. New Delhi, Springer Pvt. Ltd.

Hegab, M.M. \& Ghareib, H.R. 2009. Potential of Swiss chard (Beta vulgaris L. var. cicla) autotoxicity for weed control. Allelopathy Journal 24: 301-308.

Hiag, T. 2008. Allelochemicals in plants. Pp. 63-104. In: Zeng, R.S.; Mallik, A.U. \& Luo, S.M. (Eds.). Allelopathy in sustainable agriculture and forestry. New York, Springer.

Hue, S.M.; Boyce, A.N. \& Somasundram, C. 2012. Antioxidant activity, phenolic and flavonoid contents in the leaves of different varieties of sweet potato (Ipomoea batatas). Australian Journal of Crop Science 6: $375-380$.

Hussain, M.I.; González, L. \& Reigosa, M.J. 2011. Allelopathic potential of Acacia melanoxylon on the germination and root growth of native species. Weed Biology and Management 11: 18-28.

Hutchinson, I.; Colosi, J. \& Lewin, R.A. 1984. The biology of Canadian weeds, 63: Sonchus asper (L.) Hill and S. oleraceus L. Canadian Journal of Plant Science 64:731-744.

Hyatt, P. 2006. Sonchus oleraceus L. Pp. 275. In: Flora of North America North of Mexico (Flora of North America Editorial Committee, Eds. 1993+). 12+ vols. New York and Oxford. Vol. 19,

Jimoh, F.O.; Adedapo, A.A. \& Afolayan, A.J. 2011. Comparison of the nutritive value, antioxidant and antibacterial activities of Sonchus asper and Sonchus oleraceus. Records of Natural Products 5: 29-42.

Li, Z-H; Wang, Q.; Ruan, X.; Pan, C-D. \& Jiang, D-A. 2010. Phenolics and plant allelopathy. Molecules 15: 8933-8952.

Lima, J.M.; Silva, C.A.; Rosa, M.B.; Santos, J.B.; Oliveira, T.G. \& Silva, M.B. 2009. Phytochemical prospecting of Sonchus oleraceus and its toxicity to Artemia salina. Planta Daninha 27: 7-11.

Lotina-Hennsen, B.; King-Diaz, B.; Aguilar, M.I. \& Terrones, M.G.H. 2006 Plant secondary metabolites. Targets and mechanisms of allelopathy. Pp. 229-265. In: Reigosa, M. J.; Pedrol, N. \& Gonzalez, L. (Eds.). 


\section{Nasr Hassan Gomaa, Mahmoud Omar Hassan, Gamal Mohammad Fahmy,}

Luís González, Ola Hammouda and Atteya Mostafa Atteya

Allelopathy: A Physiological Process with Ecological Implications., The Netherlands, Springer.

McDowell, A.; Thompson, S.; Stark, M., Ou, Z.Q. \& Gould, K.S. 2011. Antioxidant activity of Puha (Sonchus oleraceus L.) as assessed by the cellular antioxidant activity (CAA) assay. Phytotherapy Research 25: $1876-1882$

Nobel, P.S. 1983. Biophysical plant physiology and ecology. San Francisco, WH Freeman Company.

Novoa, A.; González, L.; Moravcová, L. \& Pyšek, P. 2012. Effects of soil characteristics, allelopathy and frugivory on establishment of the invasive plant Carpobrotus edulis and a co-occuring native, Malcolmia littorea. PLoS ONE 7: 1-11.

Obadoni, B.O. \& Ochuko, P.O. 2001. Phytochemical studies and comparative efficacy of the extracts of some haemostatic plants in Edo and Delta States of Nigeria. Global Journal of Pure and Applied Science 8: 203- 208.

Patterson, D.T. 1986. Allelopathy. Pp. 111- 134 In: Camper, N.D. (Ed.). Research Methods in Weed Science. Illinois, Southern Weed Science Society of America.

Qasem, J.G. \& Foy, C.L. 2001. Weed allelopathy, its ecological impacts and future prospects: a review. Weed Biology and Management 4: 43-199.

Rice, E.L. 1984. Allelopathy. New York, Academic Press.

Singh, S. 2010. Phytochemical investigation of Sonchus oleraceus leaves and Citrullus colocynth root. Journal of Herbal Medicine and Toxicology 4: 159-162.

Song, F.L.; Gan, R.Y.; Zhang, Y.; Xiao, Q.; Kuang, L. \& Li, H.B. 2010. Total phenolic contents and antioxidant capacities of selected Chinese medicinal plants. International Journal of Molecular Science 11: 2362-2372.

Souza, F.M.; Gandolfi, S.; Perez, S.C.J.G. \& Rodrigues, R.R. 2010 Allelopathic potential of bark and leaves of Esenbeckia leiocarpa Engl. (Rutaceae). Acta Botanica Brasilica 24: 169-174.

Van-Burden, T.P. \& Robinson, W.C. 1981. Formation of complexes between protein and tannin acid. Journal of Agriculture and Food Chemistry 1: 77-82.

Villela, F.A.; Doni Filho, L. \& Sequeira, E.L. 1991. Tabela de potencial osmotico em funcao da concentracao de polietileno glicol $6000 \mathrm{e}$ da temperatura. Pesquisa Agropecuária Brasileira 26: 1957-1968.

Wardle, D.A.; Nicholson, K.S. \& Ahmed, M. 1992. Comparison of osmotic and allelopathic effects of grass leaf extracts on grass seed germination and radicle elongation. Plant and Soil 140: 315-319.

Xu, Q.; Xie, H.; Xiao, H. \& Wei, X. 2013. Phenolic constituents from the roots of Mikania micrantha and their allelopathic effects. Journal of Agriculture and Food Chemistry 61: 7309-7314.

Xuan, T.D.; Shinkichi, T.; Khanh, T.D. \& Chung, I.M. 2005. Biological control of weeds and plant pathogens in paddy rice by exploiting plant allelopathy: an overview. Crop Protection 24: 197-206.

Yin, J.; Kwon, G.J. \& Wang, M.H. 2007. The antioxidant and cytotoxic activities of Sonchus oleraceus L. extracts. Nutrition Research and Practice1: 189-194.

Zou, Y.; Lu, Y. \& Wei, D. 2004. Antioxidant activity of flavonoid-rich extract of Hypericum perforatum L. in vitro. Journal of Agriculture and Food Chemistry 52: 5032-5039. 